The University of San Francisco

USF Scholarship: a digital repository @ Gleeson Library |

Geschke Center

2003

\title{
Encountering Latin American and Caribbean Feminisms
}

Sonia E. Alvarez

Elisabeth Jay Friedman

University of San Francisco, ejfriedman@usfca.edu

Ericka Beckman

Maylei Blackwell

Norma Stoltz Chinchilla

See next page for additional authors

Follow this and additional works at: http://repository.usfca.edu/pols

Part of the Political Science Commons

\section{Recommended Citation}

Sonia E. Alvarez, Elisabeth Jay Friedman, Ericka Beckman, Maylei Blackwell, Norma Stoltz Chinchilla, Nathalie Lebon, Marysa Navarro, and Marcela Ríos Tobar. Encountering Latin American and Caribbean Feminisms. Signs, Vol. 28, No. 2 (Winter 2003), pp. 537-579

This Article is brought to you for free and open access by the College of Arts and Sciences at USF Scholarship: a digital repository @ Gleeson Library | Geschke Center. It has been accepted for inclusion in Politics by an authorized administrator of USF Scholarship: a digital repository @ Gleeson Library| Geschke Center. For more information, please contact repository@usfca.edu. 


\section{Authors}

Sonia E. Alvarez, Elisabeth Jay Friedman, Ericka Beckman, Maylei Blackwell, Norma Stoltz Chinchilla, Nathalie Lebon, Marysa Navarro, and Marcela Ríos Tobar 


\title{
Encountering Latin American and Caribbean Feminisms
}

Sonia E. Alvarez, Elisabeth Jay Friedman, Ericka Beckman, Maylei Blackwell, Norma Chinchilla, Nathalie Lebon, Marysa Navarro, and Marcela Ríos Tobar ${ }^{1}$

\author{
Author for Contact: \\ Sonia E. Alvarez \\ Politics Department \\ University of California at Santa Cruz \\ 1156 High Street \\ Santa Cruz, CA 95064 \\ soniaa@cats.ucsc.edu \\ 831-479-4300 (phone) \\ 831-479-7400 (fax)
}




\section{Encountering Latin American and Caribbean Feminisms}

In November 1999, nearly 1,300 women from virtually every country in Latin America and the Caribbean journeyed to the coastal town of Juan Dolio, Dominican Republic, to take part in an event that many of the region's activists have come to regard as a key arena for collectively reimagining feminism and its relationship to a wide range of struggles for human dignity and social justice. Since the first such gathering was convened in Bogotá, Colombia, in 1981, the Latin American and Caribbean Feminist Encuentros [Encounters] have served as critical transnational sites in which local activists have refashioned and renegotiated identities, discourses, and practices distinctive of the region's feminisms.

The eighth in this series of biannual or triennial meetings, the Juan Dolio event- billed as "the last Encuentro of the millennium"- - aimed to "take stock" of the past three decades of feminism in the region. Dominican organizers proclaimed the gathering's objectives to be threefold: (1) to produce a balance sheet of the last thirty years of "el quehacer feminista" (loosely, feminist action) in Latin America and the Caribbean; (2) to create spaces for dialogue that would further feminist analysis of and political positionings vis-à-vis "new" and "old" forms of oppression; and (3) to identify the mínimos comunes [lowest common denominators] that 
would foster the creation of links and alliances within the Latin American and Caribbean women's movement. ${ }^{2}$

As participants in this as well as past Encuentros, and as analysts of Latin American feminisms with diverse and extensive links to activists and scholars throughout the region, ${ }^{3}$ we recognized that the Juan Dolio meeting's agenda also offered $u s$ a unique opportunity to reflect collectively on the past and present dynamics and future prospects of feminisms in the South of the Americas. ${ }^{4}$ Our shared interest in bringing Latin American experiences more centrally to bear on recent debates concerning the "internationalization" or "globalization" of feminisms served as a further inspiration for this collaborative essay. While much of the recent literature on transnational feminist organizing has focused on how "official" international public arenas, such as the UN women's conferences, have fostered transborder links among feminists, ${ }^{5}$ scholars largely have overlooked the rich history of "extra-official" processes, such as the Encuentros, by which feminists have come together within world regions to build solidarity, devise innovative forms of political praxis, and elaborate discourses that challenge gender-based and sexual oppression. Moreover, the prevailing focus on UN-related conferences often misses how these alternative transnational linkages affect movement dynamics on the national and local levels. In analyzing the Latin American and Caribbean Encuentros, we wish to draw attention to movement-centered, intraregional feminist processes and their local effects, thereby underscoring the dynamic and mutually constitutive interplay of national and transnational feminist identities, discourses, and practices.

In a 1992 article that was the product of a collaborative, interdisciplinary, multisited conversation similar to our own, Nancy Sternbach, Marysa Navarro-Aranguren, Patricia Chuchryk, and Sonia E. Alvarez (1992) suggested that the Encuentros serve as "historical 
markers, highlighting the key strategic, organizational, and theoretical debates that have characterized the political trajectory of contemporary Latin American feminisms" (395). While this essay also will explore how the Encuentros have "marked" feminist debates in the region, we will argue that they are, in themselves, productive transborder sites that not only reflect but also reshape local, national, and regional movement discourses and practices.

While feminisms in the region arose from a wide range of political struggles and social locations, the Encuentros have enabled activists to exchange differences in perspective and construct alternative political and cultural meanings. Though often politically marginalized in their own countries, participants in these periodic regional conversations have been able to engage with others whose feminisms emerge from analogous sociopolitical conditions and colonial and neocolonial legacies. In a region where the Left initially saw feminism as a "bourgeois, imperialist import" that divided the class struggle, and where the Right and the Church have denounced it as an affront to national cultural norms and Christian family values, we argue that the Encuentros have proven key transnational arenas where Latin America-specific feminist identities and strategies have been constituted and contested.

More than just a fertile meeting ground, we maintain that these regional meetings have helped forge "imagined” Latin American feminist communities. They have been crucial in challenging masculinist, nationalist cultural norms and in creating a common (if always contested) feminist political grammar. As Peruvian feminist theorist Virginia Vargas (1999) has argued: "This transnational feminist action was oriented fundamentally toward recreating collective practices, deploying new analytical categories, new visibilities, and even new languages being invented by feminisms at the national level, naming that which heretofore had no name: sexuality, domestic violence, sexual harassment, marital rape, the feminization of 
poverty, and so on" (30). The Encuentros also have fostered new modalities of transborder activism. Indeed, a key product of these dialogues has been the formation of numerous intraregional issue-specific and identity networks as well as advocacy coalitions on a range of issues such as women's health and sexual and reproductive rights, violence against women, and women's political representation.

These periodic regional conversations also help reorient movement practices, cultural discourses, and even State policies, as participants learn from the experiences of their counterparts in other countries in the region and often return home inspired by new organizing strategies and new ways of framing their issues and demands. The discourses and strategies debated at these transnational movement sites, in turn, are translated and reworked to fit specific local and national contexts. We further suggest that local movements have benefited from the rotation of the Encuentros among different countries and subregions, as each meeting highlights issues or problems specific to the host context, allowing these to be aired, and sometimes worked out, in a supranational(ist) movement setting. We argue that the Encuentros thereby constitute a vital mediating space between national, regional, and global movement arenas.

As productive spaces of transformation—facilitating a dynamic interaction between local/national struggles and regional processes—we analyze how the Encuentros have proven critical sites of negotiation. Given class differences, rurat-urban divisions, diverse racial and ethnic formations, age and generational divides, as well as differences in sexual identities and orientations, Latin American and Caribbean feminisms' heterogeneity has defied uniform understandings of key feminist concerns such as reproductive health, education, violence against women, labor rights, sexuality, and (neoliberal) globalization. Participants have been women engaged in feminist activism in a broad (and potentially antagonistic) range of public spaces- 
from lesbian-feminist collectives, to trade unions, landless movements, research and service nongovernmental organizations (NGOs), university women's studies programs, revolutionary organizations, mainstream political parties, and State institutions. While grounded in political solidarity among women, then, the Encuentros and "desencuentros" [misencounters] within them have fostered productive debates and re-configured alliances and coalitions among the region's feminists.

In what follows, we explore the key axes of debate that produced coalition and controversy, consensus and conflict, "encuentros" and "desencuentros," among the diverse currents of the Latin American feminisms at the first seven of the se regional events-Bogotá, Colombia (1981), Lima, Peru (1983), Bertioga, Brazil (1985), Taxco, Mexico (1987), San Bernardo, Argentina (1990), Costa del Sol, El Salvador (1993), and Cartagena, Chile (1996). The story we tell examines core movement debates as they have been enacted at each of the Encuentros, paying particular attention to those held in the 1990s. Coalitions, conflicts, and controversies emerging in specific national or subregional contexts, we argue, have been restaged, and sometimes rescripted, in these transnational arenas. Debates and tensions unfolding through the Encuentros, in turn, often have been reenacted in local and national movement spheres — thus highlighting the mutual constitution of the national and the transnational. We explore three themes around which these debates have pivoted: 1) shifting conceptions of movement "autonomy" and feminisms' relationship to the larger women's movement and to other actors in civil and political society, the State, and international institutions; 2) controversies generated by the movements' recurrent "crises of inclusion" and “crises of expansion"; and 3) debates centered on differences, inequalities, and power imbalances among women, in general, and among feminists, in particular. 
The latter part of our essay turns to a detailed analysis of the most recent Encuentro, where old and new frictions were reproduced and longstanding debates among feminists reenvisioned — providing a unique window onto key challenges facing the movement today. ${ }^{6}$ As new generations and ever-more diverse actors participate in the Encuentros, the definition of what feminism is and the modalities through which feminist struggles should be waged have come increasingly under question. In the context of the shifting political and economic coordinates of the $1990 \mathrm{~s}$ — marked by neoliberal capitalism and partial, uneven democratization — the appropriate sites, targets, and goals of feminist politics, and, indeed, the very meaning of feminism itself, became subjects of intense conflict among activists. The eighth Encuentro crystallized these new tendencies and highlighted unresolved tensions that also had surfaced at the previous two meetings. To better understand what transpired at Juan Dolio, however, we first must situate this most recent gathering in light of the history of two decades of Latin American and Caribbean "encounters."

\section{The first decade of Encuentros: Negotiating politics, producing feminist identities}

The debates staged during the first decade of Encuentros, held between 1981 and 1990, reflected the shifting meanings of feminism in the region. As Sternbach et al. (1992) have argued, discussions at the first five meetings revolved around two main axes: first, the relationship between feminist movements and the male revolutionary Left; and later, as movements expanded, the relationship between feminist movements and the broad-based movimientos de mujeres [women's movements] that emerged in the context of widespread economic crises and human rights abuses throughout Latin America and the Caribbean. ${ }^{7}$ 
Key to understanding the first decade of Encuentro debates is the widely embraced-but hotly contested - ideal of feminist autonomy, considered by many to be the cornerstone of feminist identity in Latin America and the Caribbean. If feminist movements in the region have been characterized by a desire to forge alliances with diverse sectors of society (especially other women) with the goal of eradicating gender-based oppression, at the same time the ideal of autonomy has been invoked to avoid co-optation and tergiversation by actors such as political parties, the State, funding agencies, and even other social movements. Thus feminists have been deeply concerned with expanding the constituency, scope, and influence of feminism while refusing to sacrifice the ideological, political, organizational, and financial autonomy of their movements. While autonomy, very broadly defined here as the capacity to act independently, has been called the "magic word" of Latin American and Caribbean feminisms, ${ }^{8}$ it has also been (and continues to be) a thorny issue: from what and from whom exactly should feminists maintain autonomy?

In the 1970 s and early 1980 s, autonomy was invoked almost exclusively in relation to political parties or revolutionary organizations of the Left. As has been well documented, most early second-wave feminists shared a common background of experience in leftist political parties or revolutionary movements. Questioning the putative gender neutrality of the socialist project and recognizing that gender oppression transcended capitalist exploitation, many feminists increasingly opted to eschew party activism in favor of creating their own independent organizations, such as collectives, study centers, and consciousness-raising groups. ${ }^{9}$

Not surprisingly, then, the first major philosophical and strategic tension to confront second-wave feminists was between those who proclaimed themselves to be feministas and those whom they referred to as the politicas or militantes, women who continued to work within leftist 
party organizations. Most clearly present at the first two Encuentros, held in Bogotá, Colombia (1981) and Lima, Peru (1983), this conflict established "autonomy" as a practice that defined who was (and who was not) a feminist. For feministas, the Left's dismissal of feminism as a bourgeois import from imperialist nations made it impossible to create a space for feminist politics within party structures. Moreover, feminists came to view the hierarchical structures then typical of the Left as inherently patriarchal and therefore antithetical to the radical culturat ethical transformations their struggle implied. Autonomy, for the feministas, thus came to be defined as “independence from any organization that considers the battle for women's liberation a secondary goal."10 Políticas or militantes, by contrast, defended a strategy of doble militancia [double militancy] or concurrent participation in feminist and party/revolutionary organizations. For feministas at the first two Encuentros, politicas were "programmed" by the Left and attended feminist meetings only to "spread their message." Militantes, on the other hand, viewed the Encuentros (and, to some extent, "autonomous feminism") as a "petit bourgeois" project, arguing that feminists could only reach "the masses" of women through leftist party organizing and revolutionary mobilization. ${ }^{11}$

The heated debates reenacted at the Encuentros of the early 1980s inspired many activists to try to overcome such polarized positions and helped produce new understandings of how feminists might continue to be "autonomous" while retaining their links to other struggles for social justice. As one participant observed at Bogotá: “The great majority of women supported the autonomy of their organizations and practices, which does not mean that we reject the participation of women in political parties...We do argue that they should not bring their political slogans, agendas and objectives that do not address women's concerns. Nor does this mean that feminism should isolate and separate itself or ignore other social movements" (Manrique 1981). 
Indeed, after the mid-1980s, it appeared as though "autonomous feminism" had become a redundant term. The feminista/politica debate faded into the background as many feminists adopted a revised understanding of what we might call "engaged autonomy" — negotiating with or participating in leftist and revolutionary movements and parties, as well as dominant social and political institutions, while maintaining a critical and feminist stance. As transitions from authoritarian to civilian rule unfolded in Brazil, the Southern Cone, and the Andean region, still others enlisted in legal parties of the opposition—but did so while proudly and loudly proclaiming their feminist identities and insisting that the opposition embrace feminist issues and concerns.

Even as the debate over feminist participation in parties waned, the ideal of "autonomy" continued to inform feminist discourse and practice across the region, especially vis-à-vis the Encuentros. The organizing principles laid out for the First Encuentro in 1981, to be followed at each subsequent meeting, were designed to safeguard both the "autonomy" and "inclusiveness" of the event—and, implicitly, of feminism itself. Women were to attend "'a título individual,' and not as representatives or delegates of parties, trade unions, or other organizations" (Fisher 1995, 29). The meeting would be a true encuentro and not a rigidly structured political congress or more formal scholarly conference, reflecting a desire to create new, nonhierarchical, more participatory ways of "hacer política" [doing politics]. Considering early on that accepting outside funds would politically compromise the event, the first three Encuentros were totally self- financed.

Furthermore, the meetings were to be "amplios," or broad-based, anticipating the second major debate of the 1980s, surrounding the inclusionary and exclusionary practices of feminism. Like the ideal of autonomy, the proposed inclusiveness of the Encuentros has always been a 
contentious issue, as it begs the questions: Who is considered "feminist" enough to attend and, more broadly, whom is feminism supposed to convene in the first place? While participants at the Second Encuentro (Lima, 1983) widely rejected the creation of a feministómetro [feminist yardstick] to decide who was more or less feminist, later meetings would question feminism's commitment to inclusion, especially along the lines of class, race, ethnicity, and sexuality.

The dilemma of inclusion became particularly salient in part because second-wave feminist movements in Latin America and the Caribbean had always viewed poor and workingclass women as a key constituency. The 1980s, marked by brutal state oppression and rampant poverty, presented fresh opportunities and challenges for the creation of a more broad-based feminist movement, as thousands of women began to mobilize politically-though not necessarily as feminists_-in response to economic crises, political repression, and human rights abuses. In contrast to the middle-class, white/mestiza face of feminism in the early years of the movement, the burgeoning movimiento de mujeres of the 1980s was mainly comprised of poor, working-class, and/or indigenous and Black women. ${ }^{12}$

The difficulties in bridging such structurally unequal and politically disparate women's movement constituencies came vividly to the fore at the Third Encuentro in Bertioga, Brazil (1985), when a group of women from a Rio de Janeiro favela (shantytown) arrived on a bus, asking to be allowed to participate despite their inability to pay the registration fee. Though a significant number of Black and poor women were already in attendance, feminisms' enduring crisis of inclusion/exclusion literally parked itself at the door of this Encuentro. The Brazilian organizers in fact had secured numerous scholarships to enable working-class women to attend, and many participants suspected political parties had orchestrated the bus incident in an effort to discredit feminism. Nonetheless, many among the participants, especially activists from Brazil's 
emergent Black women's movement, insisted that issues of race and class had not been centrally contemplated by the Encuentro's agenda and that poor and Black women had not participated fully in setting that agenda. Of course, race and class inequalities are hardly resolved with the mere "inclusion" of nonwhite, working-class women among the ranks of feminism. As our ensuing discussion will show, the movement continues to struggle with the ways in which class, racial, and heterosexual privilege have structured power relations among women in society and within feminism itself.

If Bertioga foregrounded the dilemma of inclusion, the new challenges posed by the expansion of the movement among poor, working-class, and non-white women became dramatically evident at the Fourth Encuentro in Taxco, Mexico (1987), attended by more than 1,500 women. The unprecedented participation of hundreds of women from the movimiento de mujeres, especially from the Central American region, seemed to signal that the feminist movement had achieved its goal of convening a truly broad-based Encuentro. This broadening can be attributed to the concerted efforts of activists to bring feminist perspectives to grassroots women's organizations. The massive attendance of politically active women new to feminism, however, was perceived by some to be a mixed blessing. Many históricas ["historical" or longstanding feminists] felt that the massive presence of the movimiento de mujeres impeded strategizing about "the" feminist agenda and was counterproductive to the advancement of feminist knowledge production. Frustrated by what they perceived as an elementary level of discourse of participants from the popular classes, many expressed impatience at rehearsing the "basics" when they wished to further feminist debate.

At Taxco, a number of long-time activists maintained that the Encuentros should not be a "feminist school" for "the masses" but a space for regeneration of feminist ideas and practices. 
Others viewed this attitude as a reappearance of the feministómetro and rejected the assumption that Central American, indigenous, or poor women were not quite "feminist" enough to participate. The proposal that two Encuentros be held in the future, one for feminists and the other for the movimiento de mujeres, was met with hundreds of women chanting "Todas somos feministas" [We're all feminists], producing greater recognition that feminism does not "belong" to anyone.

The view that any woman who considered herself a feminist was a feminist—in what turned out to be a contingent solution to feminism's enduring tensions over inclusion and expansion—was echoed at the next Encuentro, held in San Bernardo, Argentina, in $1990 .{ }^{13}$ With 3,200 participants, it was the largest Encuentro held to date. Indeed, the San Bernardo meeting seemed to suggest that Latin American and Caribbean feminism had grown to massive proportions. The presence of women from a vast arena of quehacer feminista, including independent collectives, trade unions, NGOs, universities, newly created state-run women's ministries, and even elected representatives, signaled that by 1990 feminist practice was acquiring significantly new dimensions. The simultaneous presence of women from "autonomous" collectives and study centers and "institutionalized" arenas such as political parties and the State suggested that "old" debates regarding autonomy apparently had been superseded.

Another development at San Bernardo was the marked presence of formalized, regionwide movement redes [networks]. Some of these-like the Latin American and Caribbean Black Women's Network, founded at San Bernardo, and the lesbian feminist network formed in 1987 at a regional meeting that preceded Taxco—-had aimed to build solidarity, elaborate strategies to address racism, heterosexism, and other issues often marginalized from regional and national 
feminist agendas, and combat the invisibility of "O ther" women in the movement. These networks were joined at the Fifth Encuentro by new regional redes and coalitions - such as the Latin American and Caribbean Women's Health and Reproductive Rights Network-centered on national and international policy advocacy. While throughout the 1980s the latter form of networking was relatively rare, policy-focused networks gained significantly in visibility and influence during the 1990s-largely due to Latin American and Caribbean feminisms' growing involvement with the UN conference process.

The significant number of feminists now involved in gender policy advocacy and the increased visibility at San Bernardo of feminists active in legal, as opposed to clandestine, parties of the Left and Center, involved in electoral politics, or employed in State women's agencies reflected the changed political context in which feminism was embedded by the beginning of the 1990s. How feminists grappled with Latin America's "twin transitions"- to political democracy and economic neoliberalism—is explored below.

\section{Autonomy revisited: Reframing feminist strategies and identities at the Encuentros of the} 1990s

The expanded involvement of feminists in professionalized and highly specialized national and international advocacy efforts would rekindle and reframe longstanding debates among feminists throughout the region. If historic movement conflicts over autonomy, inclusion, and expansion appeared to have subsided at the San Bernardo meeting, they resurfaced with renewed vigor at the three subsequent Encuentros of the 1990s—Costa del Sol, El Salvador (1993), Cartegena, Chile (1996), and Juan Dolio, Dominican Republic (1999). 
The always contentious question of autonomy would now increasingly pivot on a new axis: the heightened engagement of some feminists with national and international political institutions - viewed by some as a "necessary step" in advancing the feminist transformational agenda but regarded by others as a dangerous slippage into or even collusion with "global neoliberal patriarchy." Tensions surrounding who was to be included in the "true" (even if always "imagined") feminist community also were recast at the regional gatherings in Costa del Sol and Cartegena around this same axis: should the activists now principally engaged in "masculinist" policy arenas be viewed simply as the "advocacy wing" of the movement or were they "sell-outs" or, worse, "traitors" to the feminist cause?

To understand the rearticulation of tensions over autonomy, inclusion, and expansion among feminists, one must consider the national and international contexts in which two distinctive "logics" that informed Latin American feminist movements in the 1990s took shape. On the one hand, a "policy-advocacy" logic drove the efforts of growing numbers of activists seeking to promote feminist-influenced gender policy through formal governmental and nongovernmental institutions. On the other, an "identity-solidarity" logic remained evident in the movement-centered development of feminist identities, communities, politics, and ideas and often was geared explicitly away from, or at least not concerned centrally with, formal institutions (Alvarez 2000).

Long before Cartagena and already presaged in San Bernardo, the policy-advocacy logic had begun to influence much local and regional feminist activism. The domestic factors behind this move were rooted in the twin transitions to democratic politics and neoliberal economic reform. On the political front, governments and parties responded to the important role women's movements had played in the overturning of authoritarian regimes throughout the region, as well 
as to a concern for attracting women voters by embracing, at least rhetorically, several feminist issues such as electoral quotas and domestic violence legislation. ${ }^{14}$ This effort provided symbolic and material opportunities for the articulation of a feminist politics from within formal institutions, especially with the founding of national women's agencies in almost all countries in the region. Feminists not only increasingly entered the State apparatus and mainstream parties but also began providing the civil society-based component of feminist policy advocacy and research by founding NGOs. This in turn led to an increase in issue specialization, "expertization," and professionalization among movement activists and organizations (Lebon 1993, 1998; Alvarez 1999; Murdock forthcoming).

These transformations were further fueled by economic developments, as neoliberal reform policies, including "rolling back the State," resulted in "subcontracting out" formerly State-provided social welfare programs to NGOs, including many of those focused on women. Feminist NGOs seeking such work were pushed to formalize their organizational practices and moderate their discourses to be able to interact with State agencies and international institutions (Craske 1998; Schild 1998).

International factors, most notably the UN conferences of the 1990s, reinforced the growing policy orientation of many national groups. ${ }^{15}$ Effective participation in the UN system required further specialized skills, greater material resources, and alliances with both government and international organization officials. Moreover, participation was in large part underwritten by multilateral, bilateral, and nongovernmental international funding agencies. Already predisposed to funding organizations with a more professional (and often governmental) orientation and structure, they privileged those groups willing to turn most of their energies toward the international arena during the 1990s (Alvarez 1998). 
The interplay of these domestic and international influences inspired growing numbers of activists to forge intra- and interregional linkages to participate in UN processes. They hoped international pressure could be "boomeranged" back onto national and local governments to implement the women's rights legislation and programs begun during democratization processes (Keck and Sikkink 1998). As explained by one of the most prominent leaders of the preparatory process for the 1995 Fourth World Conference on Women (FWCW), "one of the significant changes (in the 1990s) has been the modification of an anti-statist posture to a critical negotiating posture in relation to the State and to formal international spaces" (Vargas 1998a).

By the 1990s the policy-advocacy logic operated as both a complement and competitor to the identity-solidarity logic of more grassroots-oriented, less-professionalized movement activists. On the one hand, the logics complemented one another as NGO coordinations for UN conferences such as Beijing drew upon contacts and discourses forged through preexisting, mostly informal, identity and solidarity networks, while local feminist advocacy efforts benefited from the legitimation of some historical feminist issues, now officially embraced by the UN and nominally endorsed by many of the region's governments.

However, conflict arose when the privileging of leaders and discourses more amenable to traditional policy fora compromised feminist solidarity. Membership having its privileges, the disproportionate access to resources and governmental "ears" (and "wallets") on the part of activists following the policy-advocacy logic became a deep source of contention among feminists throughout the region. In particular, the obvious moderation of feminisms' more radical social critiques and prescriptions triggered the visceral condemnation of all things "institutionally oriented" by a new segment of the movement, which revived the ideal of autonomy, now recast in relation to the changed conditions of the 1990s. 


\section{Costa del Sol, El Salvador, 1993}

Few expected that renewed tensions concerning autonomy would overwhelm the agenda at the Sixth Encuentro held in Costa del Sol, El Salvador, in late 1993. After all, the very fact that Central America_-where most feminists had continued to engage in "double militancy" in revolutionary parties and radical popular movements throughout the 1980s and into the 1990shad been chosen as the site for the sixth regional feminist gathering seemed to suggest that many had set aside their earlier conviction that party activism and feminist practice were ontologically incompatible. It also signaled a recognition that Central American feminism—with its unique history in Costa Rica, its birth in the fires of revolution and civil war in Nicaragua, El Salvador, and Guatemala, and its links to struggles against military occupation and for land in Hondurashad something important to offer feminists from other parts of Latin America and the Caribbean.

The road to attend previous Encuentros had been long and arduous, especially for Guatemalan and Salvadoran women emerging from bloody civil wars. The decision to hold this Encuentro in war-torn El Salvador had been made the year before at a subregional Encuentro of Central American activists. Held in Montelimar, Nicaragua, the meeting was intended to bolster the movements' strength and visibility locally and foster autonomy, leadership, and democracy among Central American feminisms. Interventions by Nicaraguan revolutionary activists, urging their counterparts in Guatemala and El Salvador not to put their feminist demands on the back burner-even when the social movements in which they participated called for unity-proved to be crucial in this respect, especially for the Guatemalan women who later succeeded in getting women's demands into the 1994 Peace Accords. 
At the same time, tensions around class and sexuality surfaced at Montelimar, when peasant and poor women expressed their discomfort at the relatively posh accommodations in a context where their children and communities lacked so much, even though Nicaraguan organizers had intended to provide participants with a relaxing setting in which to engage in debate. The visible presence of lesbians also disconcerted some, while others, including several of the revolutionary women, took advantage of the opportunity to learn about something only whispered about during the war: sexuality.

In the process of preparing the Sixth Encue ntro, sharp divisions arose among the organizers - a politically diverse group of women, including exiles and refugees in Mexicoaround the inclusiveness or exclusiveness of the Encuentros and, even more importantly in this case, about leadership, debate, and decision- making styles carried over from the revolutionary movements. Some of the organizers felt that others had simply transferred their revolutionary dogmatism and intolerance into feminism. While recognizing the efficiency and logistical capacity of some of these leaders, many called for more democracy, tolerance for difference, and a more nurturing environment in which to carry out their activism.

This seemed all the more imperative since organizers of the Sixth Encuentro had to confront serious opposition from rightwing politicians who denounced all feminists as lesbians, communists, and members of the Farabundo Martí National Liberation Front (FMLN), even issuing death threats. Furthermore, Salvadoran officials prohibited Cuban women from entering the country, and when participants from other countries began to arrive, some one hundred were detained at the airport. Indeed, the Encuentro ultimately took place under the protection of the United Nation peacekeeping forces, at the time overseeing the Salvadoran peace process. 
Unbeknownst to most participants, women who had acquired security experience during the wars also protected the Encuentro day and night.

Despite this conflictual local political backdrop, the major bone of contention at Costa del Sol turned out to be whether the Latin American feminist movement should participate in the region-wide preparatory process for the Beijing Conference to be held in 1995 and in what capacity. Shortly before the Encuentro, it was disclosed that a very conservative Chilean businesswoman with no connections to the feminist movement had been designated as NGO Forum Coordinator for Latin America. ${ }^{16}$ A group of feminists-mostly from Chile-resolved to replace the officially selected representative with a candidate from "the movement." After gathering endorsements from various feminist groups throughout Latin America, they persuaded the Conference Secretariat to substitute the official nominee with Virginia Vargas, a founder of the well-known Peruvian NGO, Centro de la Mujer Peruana Flora Tristán. At Costa del Sol, the group announced that the Conference Secretariat had accepted their alternative nominee, explained how the substitution had been made, and also revealed that there would now be a process of organizing feminist NGOs toward Beijing, funded by the US Agency for International Development (USAID).

The news fell like a bombshell. Most participants had no prior experience with UN conferences and had not yet heard of Beijing. Moreover, the vast majority of Latin American feminists had had little contact with the new international networks involved in the world summits. Even though the UN Decade on Women began in Mexico City in 1975, UN conferences had had limited impact on mobilizing efforts among most Latin American feminists, with the partial exceptions of Mexico and Brazil. More concerned with national developments during the 1980s, very few had participated in the "Decade Closing" UN Women's Conference 
in Nairobi in 1985, which coincided with the Third Encuentro in Bertioga (Navarro 1998). As we noted above, the situation began to change somewhat in the early 1990 s, as preparations for various UN conferences stepped up. At the time of the Sixth Encuentro, however, most Latin American activists did not know what an NGO Forum was or what was supposed to happen there.

Funding by USAID was also a problem for many. Beyond general suspicions fueled by the long history of U.S. political intervention in the region, the memory of USAID's closeness to the CIA and its actions in Central and South America, especially during the Reagan era, made acceptance of funding from the agency highly problematic, to say the least (Mello 1994). Most supported the rejection of the Chilean businesswoman and even agreed with the nomination of Virginia Vargas as a fait acomplit. But many nevertheless protested the seemingly undemocratic process pursued in selecting Vargas and wondered why other "movement candidates" had not been considered. The ensuing debates at Costa del Sol were heated and fraught with confusing information and rumors of all kinds, including the high cost of the Encuentro-information revealed the following year suggested that the organizers received close to half a million dollars from foundations.

At Costa del Sol, those feminists who were already involved in NGOs and accustomed to dealing with foreign funders favored participating in the preparatory work that would lead to Beijing. Others, who were determined to maintain the independence of the feminist movement from international funders and the State, opposed all involvement in Beijing. That is, they were intent on defending the "autonomy" of the movement—now redefined by many as pivoting on feminisms' relationship to formal or "mainstream" institutional arenas and the movement's capacity to set its own agendas independently of those institutions. The debates at Costa del Sol 
also reopened the discussion over what many saw as the perverse role of foreign funding in the movement, especially in view of the proliferation of Northern-sponsored NGOs, and the concern that such funding might politically compromise or worse come to control the feminist agenda.

Those who refused to participate and decided to voice their opposition to Beijing were in the minority. Others prepared their participation in the NGO Forum for the following two years under the direction and guidelines of the United Nations Development Fund for Women (UNIFEM), which sought to promote Beijing Initiative Groups in every country -- though many questioned the transparency and inclusiveness of their organizing methods. The Initiative Groups sponsored numerous national meetings as well as provincial and subregional gatherings and a final regionwide meeting held in Mar del Plata, Argentina, in conjunction with the official Economic Commission for Latin America and the Caribbean (ECLAC) regional preparatory conference in September 1994.

Though a detailed discussion of the Beijing process is beyond the scope of the present essay, ${ }^{17}$ it would be difficult to overstate its impact on feminist movement politics and gender policy throughout Latin America and the Caribbean. For nearly two years prior to the Fourth World Conference on Women (FWCW) itself, many of the movements' ongoing organizing and lobbying efforts were absorbed by local, national, and regional preparations for Beijing.

Sizeable material resources and political rewards accrued to those sectors of the movementlargely the expanding number of professionalized NGOs specializing in policy advocacy—who devoted the bulk of their energies to influencing national government reports on the status of women and worked to integrate feminist perspectives into the regional and global Platforms for Action. 
Given its origins in earlier exchanges facilitated by the Encuentros, "it is not surprising that the Latin American and Caribbean NGO Coordination for the FWCW-headquartered in Lima and charged with articulating six sub-regional 'focal points' in the region ${ }^{18}$ - declared in its core organizing slogan that Beijing would serve as both 'Texto y Pretexto' (Text and Pretext) for feminist movements in the region" (Alvarez 2000, 43). That is, while feminists involved hoped to influence the actual texts of government reports and UN documents, many also saw Beijing as an exceptional opportunity, a pretext, for remobilizing and revitalizing feminist movements and fostering public debate about women's subordination. ${ }^{19}$ A dynamic interplay of text and pretext, then, guided much of feminist NGOs' involvement in the UN process and had a number of positive consequences for local movement discourses and practices (Alvarez 1998; Vargas and Mauleón 1998; Alvarez 2000).

Still, participation in the Beijing process conferred "relatively few actors in local movement arenas with greater access to political, cultural, and 'actual' capital." The growing involvement of many activists in intergovernmental advocacy therefore sometimes “'translate[d]' locally in ways that exacerbate[d] existing power imbalances among activists and organizations," (Alvarez 2000, 56) unsettling intramovement solidarities while accentuating class, racial-ethnic, and other inequalities among activists (Friedman 1999; Vargas and Mauleón 1998).

With respect to political capital, for instance, local leaders of the Initiative Groups gained greater access to national policy microphones and became the privileged interlocutors of domestic policy-makers and international donors alike. When funding "civil society" involvement in the national and regional Beijing processes, donors clearly favored "larger, already well-resourced, more professionalized feminist NGOs whose work has measurable 
'policy relevance' over smaller, less formalized, typically more grassroots- or identity-solidarityoriented movement organizations" (Alvarez 2000, 57; see also Alvarez 1999). Finally, as Vargas (1998b) herself has argued in an insightful retrospective essay, "[t]he equilibrium between 'text' and 'pretext' did not resist the confrontation of the global with the local. [Locally,] the emphasis on the text ... prevailed, while strategies aimed at cultural, symbolic and political transformations [were] relegated to a secondary plane ..." (14). Beyond aggravating tensions between policy-focused and more movement-centered activists and groups, then, the Beijing process brought growing political divergences among local feminists into the full light of day. Those conflicts were played out with unprecedented virulence on the transnational stage provided by the Seventh Encuentro in Cartagena, Chile.

\section{Cartegena, Chile, 1996}

The absorption of much of the movement's energies by the Beijing process had compelled Chilean organizers of the Seventh Encuentro to postpone it until November 1996. From May 1995 onward, Chilean activists held several national meetings to plan the regional event, only to find that the differences and the ill will between those engaged with formal institutions and those defending the absolute autonomy of the movement were increasing. Indeed, Chileans identified with the local Movimiento Feminista Autónomo (MFA), who ultimately dominated the local organizing committee for this Encuentro, deliberately provoked the confrontation between these two tendencies or "logics" in the movement. In appropriating the term "autonomous," which, as we argued above, historically was almost synonymous with feminism, they tried to mark unequivocally their fundamental difference with those they 
pejoratively dubbed the institucionalizadas, that is, those who worked "inside" governmental and nongovernmental institutions. ${ }^{20}$

In Chile, the autónomas had emerged as an explicit political current in 1993, proclaiming that their erstwhile feminist "sisters"- who had chosen to occupy the new "women's spaces" in parties and the State or had founded professionalized NGOs_- had "institutionalized" the movement and "sold out" to the forces of "patriarchy and neoliberal capitalism," using "the movement as a springboard to attain spaces of power" instead of working to "strengthen the movement." In explaining the origins of their autonomous current, the Chilean MFA maintained:

The constitution of the autonomous feminist movement coincides with the process in which feminism finds itself in general with regard to defining its relationship to the system. In a period in which the ideology of neoliberalism is taking root . . feminism could not remain at the margins of this historic predicament, and therefore two political currents have assumed a clear profile. One, led from within institutions, is represented fundamentally by women who work for NGOs, whose ideology responds to the neoliberal ideology of pragmatism from the standpoint of gender . . . and which attempts to make invisible and supplant the movimiento social de mujeres and the feminist movement. The other current, the autonomous one, is the one that "stands on the other corner" (se "para en la otra esquina"), from the standpoint of the movement and the protagonism of women, questioning the values of the system and its institutions. (Lidid and Maldonado 1996, 2)

Divisions among Chilean feminists were sharp, spurred largely by differences in how activists responded to the State in the post-Pinochet era. ${ }^{21}$ While many readily enlisted in women's 
agencies and formal politics under the new Christian Democratic and Socialist Party ruling coalition, others vehemently criticized what they perceived as the unwarranted moderation of the former opposition's transformational agenda. For several months preceding the Encuentro, the polarization rending Chilean feminisms, which had been further accentuated by the national Beijing preparations, rapidly became "transnationalized" through electronic communication and movement journals with significant regional circulation, such as mujer/fempress and Cotidiano Mujer, which published several articles on the debates surrounding autonomy then raging among Chilean feminists. In May 1996, Montevideo-based Cotidiano Mujer published a letter signed by 124 Chilean feminists denouncing the manipulation of the Encuentro by the MFA: "[W]e declare that neither the conditions nor the guarantees necessary for an open and democratic Encuentro, as the previous Encuentros have been, exist in Chile. The organizers have set up a model in which each participant will be defined according to their unilateral conception of what a feminist is" (Cotidiano mujer 1996, 3). The letter urged another country to take over the organizing as soon as possible. Another letter, authored by Virginia Vargas, urged the organizers of the six previous Encuentros to mediate the conflict among the Chileans and to help create a space open to democratic dialogue. In the same issue, Margarita Pisano, a leading MFA figure, responded in an interview by lashing out at formalized feminist NGOs and networks, their wealth, the ir power to dictate the agenda, their corruption, and their lack of democratic commitment. She saw irony in their willingness to spend large sums of money preparing their trip to the Beijing conference and their lack of support for the Chilean Encuentro.

The acrimonious debates preceding this Encuentro clearly did not augur well for things to come. When the seven hundred participants began to arrive in Cartagena, a working-class resort near Santiago de Chile, tensions were high. The organizers planned the meeting along three 
themes: "1) Political and philosophical frameworks of the various currents of Latin American feminism: Autonomy, movement, feminist ethics, relations with the women's movement, and strategies in the context of the globalization of neoliberalism. 2) The hidden and discriminated dimensions of feminism: the indigenous women, Black women, lesbians, poor women...in us. 3) Unraveling our strategies. How do we change the world?" (Comisión Organizadora del VII Encuentro, 1996).

The first two axes were presented in two rigidly organized plenary sessions in which presenters read position papers, a format that many saw as violating the non-hierarchical, participatory organizing principles that, as noted above, had guided all previous Encuentros. Furthermore, speakers engaged in an angry display of insults, accusations, recriminations, and vicious attacks, a behavior never seen before in an Encuentro and very painful for all to watch. The highly theatrical Bolivian autónoma group, "Mujeres Creando" [Women Creating], used particularly violent language, making personal attacks, and, after Vargas addressed the assembly, displayed a banner stating "Watch out! Patriarchy now dresses up as a power-hungry woman." In the afternoon, participants were scheduled to divide into the two "camps" demarcated by the organizers—autónomas and institucionalizadas — to discuss the position papers. However, a third grouping, refusing to identify with either of these two camps, met under the denomination of ni las unas, ni las otras [neither the ones nor the others]. In a statement drafted at this "third position's" workshop, attended by between 300 to 400 women, participants criticized the excessively policy-centered focus of some sectors of the movement and stressed that "we need to evaluate our own practices ... and discuss how to revitalize the feminist movement in our countries, recognizing its current fragility." At the same time, they interrogated the essentialism and intransigence of the autónomas, arguing that "(a)utonomy is not necessarily about whether 
one does or does not have funding, it doesn't mean not having an ideological project, nor is it about the demonization of institutions." Instead, autonomy was defined as an individual and collective commitment to claiming arenas from which to transform women's lives and society as a whole (“Desde 'ni las unas' ..." 1998).

On several occasions, as insults were hurled right and left, it seemed that Cartagena, the supposed "encuentro del diálogo," might well be the last Encuentro. However, the majority on the "two sides," including those who declared to be on "neither side," were resolved to avoid a full-scale "break-up." But the lack of dialogue meant, among other things, that Cartegena was largely a missed opportunity for an analysis of the positive and negative consequences of the Beijing process for national and regional feminist politics. Instead, the Beijing legacy contributed to the polarization of participants and hovered like a ghost over Cartagena.

\section{The "Last Encuentro of the Millennium": Enduring frictions, renewed debates, and} emergent possibilities at Juan Dolio, Dominican Republic, 1999

Many activists had feared that the polarized and acrimonious "showdown" that was Cartagena would be reenacted at the Juan Dolio gathering in November 1999. Indeed, a number of feminists, particularly those labeled institucionalizadas (even if they didn not self-identify as such), shied away from attending the meeting. However, as will become clear in what follows, the Eighth Encuentro did not simply reproduce longstanding tensions surrounding movement autonomy, inclusion, and exclusion. Instead, it again proved to be a critical transnational site in which "old" frictions were renegotiated if not "resolved" and where feminist identities were refashioned and new and some longstanding movement debates recast. 
Despite the abstention of some policy-oriented activists who feared a repeat of Cartagena, the Eighth Encuentro brought together nearly 1,300 women. The Organizing Committee deliberately chose to focus not on specific topics but on three political axes of discussion [ejes políticos], which they intended to be broad enough to allow for an analysis of "patriarchy in its complexity and as a system": (1) "old and new forms of domination" facing feminists; (2) the dynamics of feminism as a social movement, especially in relation to power relationships among women within it; (3) prospects for forging alliances across regional feminist movements based on minimum common values and goals.

A fourth component—no less essential to the organizers—-was what they referred to as the "eje transversal" [transversal axis], intended to recapture the "cultural-symbolic-relational" elements of feminist practice. ${ }^{22}$ This methodological approach, correctly identified as a "political choice," was intended to foster creative, dynamic, and innovative forms of interaction among participants. Each participant was to select one of ten groups, organized around "dynamics" such as theater/role-playing, poetry, dance/corporal expression, collage, body painting, and so on. The results of each group's interaction were to be presented at the two plenary sessions. The equal importance given to form and content—as well as to art and "culture" as privileged venues in the quest for new modes of communication and sociability—also was evident in the plethora of cultural events including video, theater, dance, and musical performances offered every evening. This transversal axis was designed to serve as an equalizer between those with differing capacities and patience for the privileged verbal and analytic modes of movement work by offering a variety of options for communication, expression, and participation. Those who did not wish to take part in one of the ten preestablished groups were able to create their own (not necessarily following the proposed methodology). At the same 
time, a "parallel" program offered more than thirty participant-initiated workshops, discussion groups, and other activities.

\section{Corporal and expressive feminisms}

This call for a "new feminist ethic" was embedded in a form of cultural feminism, which, though always part of Encuentros, permeated the organizational structure of Juan Dolio. This tendency was expressed in an emphasis on the body, on corporal and artistic expression, on knowledge of the self and on inner strength, as well as an emphasis on "women's values," on common experiences as women, and a shared sense of strength from women's "herstories" [el ser mujer].

The strong presence of cultural feminists among the Dominican organizers, a number of whom self-identified as autónomas, and the relative absence of more policy-focused Dominican feminists certainly reinforced this trend. However, the Organizing Committee's methodological choices were also part of a strategy that seemed aimed at displacing the acerbic political debates of Cartagena and at healing the wounds of that highly divisive meeting.

Indeed, the methodology chosen generally was successful in diffusing tensions. The small groups certainly facilitated inclusiveness and possibly aided in the search for common strategies. Still, while this emphasis on the corporal over the verbal or analytical delighted some Encuentro participants, it disconcerted others. On one hand, many first-time attendees seemed to appreciate the chance to get to know other participants and engage in self-expression in an atmosphere that minimized differences in age, previous feminist experience, and political tendencies. On the other, a number of women found the approach frustrating because it offered little guidance for strategizing about changing political conditions and yielded little more than a 
shopping list of problems or issues presented at the final plenary. Jokingly referring to the morning workshop approach as "feminism lite," women who proclaimed they wanted to "discuss" rather than "touch" their feminism formed their own formal or informal discussion groups. The largest of these groups, known as the discoteca group because of its meeting venue, drew dozens of activists of all ages and levels of experience to discuss concrete movement strategies.

\section{Bridging the divide between autónomas and institucionalizadas?}

Beyond the tensions between "corporal" and more "cerebral" approaches to feminism, the Eighth Encuentro marked a significant turning point in the conflict between autónomas and institucionalizadas. The Juan Dolio Encuentro revealed the gradual diffusion of that conflict-a process initiated in the aftermath of the Seventh Encuentro in Cartagena and accentuated by the "autonomous Encuentro" held in Sorata, Bolivia, in 1998.

Despite the presence of a significant number of autónomas who had attended the Sorata meeting and the fact that a number of them actively participated in the Dominican organizing committee, the Eighth Encuentro did not turn out to be yet another "standoff" between two polarized sectors of the movement. This Encuentro was instead characterized by the diversity and heterogeneity of issues aired rather than by the predominance of single-issue discussions and by the apparent unwillingness of the majority of participants to engage in confrontations such as those staged in Cartagena. Moreover, it seems that the very level of animosity displayed in Chile had an unexpected effect on the collective Latin American feminist imaginary: it imposed the necessity of healing the wounds and exorcising the trauma that many felt the Seventh Encuentro had provoked. 
Moreover, Cartagena arguably produced a tension at the regional level between autónomas and institucionalizadas that did not find a direct counterpart in most individual countries other than Chile—with the partial exceptions of Bolivia, Argentina, and perhaps Mexico. Still, the "new" debate about autonomy staged in Chile was reenacted in many countries during the latter half of the 1990s—-foregrounding already present, though sometimes not yet fully articulated, local concerns about the excessive "institutionalization" of the movement. In this sense, the Encuentros again had served as a vital space of mediation between the local/national and transnational movement arenas.

In retrospect, it is difficult to speak of genuine confrontation in a conflict that developed as a unilateral criticism on the part of the autónomas, but never had an organized interlocutor defending the (imputed) opposite position, the so-called institucionalizadas. Since the beginning of the 1990s, the latter group was increasingly absent from more movement-based spheres where the autónomas concentrated their action. Instead, they tended to avoid or ignore the criticisms and issues posed by the autónomas and focused on strengthening policy advocacy strategies. The feminists who did acknowledge the autónomas as legitimate interlocutors were precisely those who did not identify with the dichotomized scenario the autónomas tried to construct. They were, in general, active in "movement spheres" while at the same time contributing to other processes promoted from more "institutional" venues, such as NGOs. As it turned out, very few feminists took it upon themselves to defend a purely institutional strategy to advance a feminist agenda.

As new issues and actors emerged in the movement, and the context in which the autónomas/institucionalizadas conflict arose had changed, the confrontational logic constructed around that axis seemed to have reached a stage of inevitable exhaustion. For instance, whereas, 
as we suggested above, Beijing haunted discussion at Cartagena, at Juan Dolio it had been transformed into a "white elephant"-an issue everyone now "saw" clearly but about which enough had been said. Internal conflicts among the autónomas themselves also contributed to their loss of visibility and power within the movement and to the consequent diffusion of conflict. The experience in Sorata, Bolivia, during the first (and, thus far, only) self-proclaimed Autonomous Feminist Encuentro had a devastating effect on the autónomas' capacity to organize and act as a unified political current. The event, ironically, was rife with confrontations regarding who could be considered a "genuine" autonomous feminist. The participation of younger women and the airing of different interpretations of what autonomy meant for feminism were among the most conflictive issues. This experience, together with fragmentation among groups of autónomas in different countries, translated into a clear weakening of their position even before the Eighth Encuentro. This became apparent in the working group the autónomas organized at Juan Dolio independently of the official program, which never gathered more than thirty women at a time.

Though the "autonomous" current was never internally homogeneous, it was further rent by internal conflicts. Hence, it is no longer possible to speak of a sole, coherent autónomas discourse or current. ${ }^{23}$ This fragmentation explains in part why despite the autónomas' influence in the local organizing committee, they were not able to play a predominant role in Juan Dolio. On the contrary, as discussed above, the organizers made an explicit political decision to avoid confrontation. The meeting's methodology was harshly criticized by the autónomas who attended the Encuentro, who denounced it as a strategy to erase the Encuentro in Cartagena from feminist historical memory in an attempt to ignore real and important differences among feminists. 
Finally, the processes of critical introspection embarked upon by many feminists who have focused primarily on policy advocacy during the past few years also seem to have contributed to the diffusion of this conflict. Even though this is not necessarily a widespread phenomenon, a small but significant number of históricas who have formed part of the "advocacy wing" of the movement attended the Eighth Encuentro, showing a disposition to reflect critically upon their activism during the 1990s. Some have acknowledged the need to assess the dangers of a political strategy that rests solely on policy advocacy and negotiations with governments and international organizations and is primarily aimed at influencing the construction of institutional or policy agendas. Many acknowledged, in turn, the legitimacy of some of the autónomas' criticisms. The fragmentation and weakening of the autónomas' position, together with increased self-criticism on the part of many so-called institucionalizadas, thus facilitated a diffusion of the conflict between these sectors.

At Juan Dolio it nonetheless became evident that much of the autónomas' discourse and critiques had found resonance among many Latin American and Caribbean feminists. They were able to place key issues on the agenda and forced an important debate about the costs and benefits of "institutionally centered" national and international feminist strategies that otherwise might have gone untouched. In this respect, the Eighth Encuentro sat at a crossroads between the conflicts manifest at previous Encuentros and what can be expected of the movement in the future. While in Chile the Encuentro had revolved around the confrontation between two putatively polarized political strategies, the Dominican gathering lacked a central single issue around which feminists positioned themselves and, on the contrary, provided fertile soil for a multitude of issues to flourish. 


\section{Crossing generational divides: The emergence of a young feminist movement and the renegotiation of identity and power}

While there have always been distinct political cohorts in Latin American feminisms, the articulated presence of a new generation of feminists at this Encuentro marked a shift in the region's second wave. The growing number of young feminists in several countries has fueled the proliferation of organizations comprised mostly of this newer generation, such as the Colectivo Feminista Bajo Sosphecha ("Under Suspicion” Feminist Collective) in Chile, which formed in response to the institutionalization/autonomy divide in the Chilean feminist movement. The organization has tried to organize across this political divide, even though some of its members work in NGOs. In Mexico, a nascent movement has been operating since the late 1990s, leading to the first National Encuentro of Young Feminists in $1998{ }^{24}$ Comprised of largely urban youth, the formation of this generation of feminists has been influenced by the 1994 Zapatista uprising, the student movement, and university women's studies programs, as documented by such publications as Lunatika (Feminismo, Política, Sexualidad, Cultura), “a publication by young women, for women." 25

With the increased presence of young feminists at the Eighth Encuentro, an important development at this meeting was the articulation of this newer generation's perspective in the declaration they presented at the final plenary. Emerging from the workshop, "Young Women of the End of the Century," convened by Bajo Sospecha and attended by over fifty women, the statement called for a greater recognition of those who entered the feminist movement in the 1990s. Drawing attention to their increased participation in the workshops and plenaries, they viewed the Eighth Encuentro as a milestone in the visibility of young women within the movement. While acknowledging that they were beneficiaries of the gains secured by earlier 
generations, they critiqued the lack of openness in other movement spaces and the absence of strategies to involve new activists.

A decisive intervention of young feminists was their claim that "feminism is defined by its practice of power," challenging feminists to examine power relationships internal to movement organizations. Critical of the ways in which more established feminists have failed to share power, they denounced a division of labor in which "some feminists write, think and speak, while others make photocopies, hand out pamphlets, and format texts .... This seems to us to correspond to patriarchal practices of doing politics that result in the establishment of hierarchies, the invisibilization of some and the exclusion of others." ${ }^{26}$ The statement was a call to dialogue and a demand for recognition of a younger generation of feminists emerging from very different historical, economic, and political circumstances. As daughters of the "lost decade" of the 1980s who had grown up under authoritarian regimes, armed conflicts, and economic crisis, they had witnessed the collapse of utopian visions of social change and a crisis in the political party system as well as the revalorization of democracy. While acknowledging that earlier feminist struggles had gained more spaces for women, young activists noted that their generation of feminists have come of age in a world marked by globalization, technological development, and neoliberalism, in which the forms of oppression they confront are often economically more brutal while socially more subtle, factors that distinguish their experiences from those of past generations.

To a large extent, this new generation of activists has emerged out of the institutional spaces won by feminism—such as NGOs and university women's studies programs—rather than out of the radical mass movements, political parties, or the Left of the past; in fact, some expressed a sense of loss for not having witnessed the feminist militancy and mass mobilizations 
of "yesteryear." Further, this generational difference in political trajectories may also inform young women's expressed desire not to repeat errors of the past, such as "internal conflicts that arose from the root of the relationship with the State and other political actors." As a distinct new sector of the move ment whose concerns are often neglected by the "larger" feminist agenda, young feminists also articulated a critique of discourses of diversity and pluralism, arguing that "often the idea of diversity implies more precisely difference and inequality... and does not permit the recognition or legitimation of others and their experience."27

\section{Discourses of diversity}

The greater visibility of young women at Juan Dolio suggested that, by the turn of the new century, Latin American and Caribbean feminisms' enduring tensions around issues of inclusion had dovetailed with the movements' recurrent conflict over expansion. Inclusion was no longer a matter of how best to deal with feminism's "Others"- that is Black women from the favelas or activists in popular women's groups. "Feminisms' Others," the Juan Dolio meeting made crystal clear, were now actively reinventing "other feminisms"-forcing a reimagining of the region's "feminist community" that would account for its expansion among and resignification by "popular feminists," Afro-Latin American feminists, young feminists, lesbian feminists, and so on. Indeed, the history of the Encuentros can be read as one of conflict and debate around the ways that race, ethnicity, class, and sexual orientation are organizing axes in gender oppression and shape how gender is experienced in daily life.

Given second-wave feminisms' historical relationship to the Left, a clear class critique of women's oppression as well as a strident anti-imperialist stance has been evident in the regional meetings ever since Bogotá. During the first decade of Encuentros, however, far less attention 
was paid to how gender identities and social stratification not only are determined by class and gender but also by race and ethnicity, sexuality, and other vectors of power that shape women's subordination.

As Peruvian feminist Maruja Barrig suggests, early second-wave feminists' origins in the Left made them "tributaries of a [Marxian] tradition of interpretation of the nation that subsumed the ethnic-cultural under rigid categories of proletarians, peasants, and students" that "blinded" most white/mestiza activists to racialethnic inequalities among women (Barrig 2001). Despite the absence of discussion of race early on, Sergia Galván observes that Black women participants have been attending the Encuentros and caucusing since 1983: "The ethnic/racial question has headed the list of absences and knots in the agenda of Latin American feminism, in spite of the fact that, from 1983, Black women present at the Encuentros have tried to open spaces in said agendas, however, it is clear, that [we do this] from the periphery and from a minority position where only we have felt called to do so. Indigenous women have done the same in the last two Encuentros [in 1990 and 1993]" (Galván 1995, 34).

Black women who attended the Fifth Encuentro in Argentina decided to hold a regional meeting of their own to reflect upon their organizational experiences within the feminist movement and national Black movements in Uruguay, Brazil, Ecuador, Columbia, Panama, Puerto Rico, and the Dominican Republic. And in July 1992, they convened the First Encuentro of Black Women of Latin America and the Caribbean, held in the Dominican Republic, where 350 Black women from thirty two countries came together for six days of intense dialogue, strategizing, and celebration.

Since then the diversity of feminist actors and struggles has been increasingly recognized within the Encuentros but not without substantial debate and negotiation. For example, though 
lesbian feminists always have been key actors in feminist and women's movements throughout the region, they have had to struggle to put the issue of sexual orientation on the feminist agenda. This despite the fact that Encuentro workshops focused on lesbian issues are often among the most well attended, where participants overflow into the hallways. To confront invisibility within the movement, they organized a Network of Latin American and Caribbean Lesbian Feminists. The first regionwide lesbian-feminist meeting was held in 1987 immediately preceding the Fourth Encuentro in Taxco, and they since have met on several other occasions (Mogrovejo 1998, 2000).

While conversations at Juan Dolio revealed that diversity was now invoked as an affirmative ideal by most in the movement, the social, economic, historical, and cultural differences and inequalities among women were not frontally addressed at the Eighth Encuentro. This was most evident in participants' conflation of ideological diversity with socioeconomic, cultural, racial, and sexual differences and inequalities. As is still often the case among feminisms in the United States, the reduction of differences to a form of feminist pluralism makes it seem like all feminisms and feminists operate equally on the same social terrain and fails to grapple with how that terrain is fractured by profound social and economic inequities and forms of prejudice.

This relative neglect of inequalities among women—even as feminist "diversity" was celebrated—was compounded by the continued search for a "minimum common denominator" at Juan Dolio. A faction at the meeting called for the feminist movement to create a common strategy—to which others replied, "we're a movement, not a party." While some expressed anxiety that too much difference would de-center historic feminist concerns or fragment the movement, several of the sessions, mostly in the Alternative Program, focused on new strategies, 
such as the panel on "Estrategias para incidir desde el Feminismo para combatir el racismo y el sexismo" [Strategies for combating racism and sexism from within feminism]. Lesbians also organized several sessions and held their own ad-hoc caucus meeting where ideas, strategies, and reports were shared.

Despite this increased recognition of "diversity," however, indigenous women were numerically invisible at the Eighth Encuentro, even though they have emerged as a significant transnational force in women's organizing in the region over the past decade. A single workshop, fittingly entitled "La identidad india 'invisible': un racismo feminista?" [The invisible Indian identity: a feminist racism?], highlighted their absence from the strategies and agendas formulated at the Encuentro. Geography may have been one factor contributing to the relative absence of indigenous women, since their participation in past Encuentros has been most visible in subregions or countries with mobilized indigenous struggles. A second factor was the expansion of indigenous women's independent organizing on a continental level.

Although indigenous women participated in earlier Encuentros, the Fifth in Argentina had marked a visible shift, as indigenous women organized their own workshop to discuss opposition to the 500 Year Celebration of Columbus' so-called discovery of the Americas and proposed that October 11 be proclaimed Indigenous Women's Day. If the Encuentros facilitated networks such as the Lesbian Feminist Network or that of Black women, it can be argued that indigenous women's regional networks were formed in part as a consequence of desencuentros or misencounters. Yet, as distinct from other regional networks, indigenous women's organizing occurred at a juncture when a transnational indigenous movement was growing; thus, while having zones of contact with both the feminist and larger women's movement, it developed its own independent structure. 
In fact, the preparatory process for Beijing, rather than the Latin American feminist Encuentros, provided the catalyst for sustained regionwide meetings of indigenous women. ${ }^{28}$ At the Mar de Plata preparatory meeting for Beijing, indigenous women were unsettled by their lack of representation and by the fact that an "advisor" had been assigned to deal with their concerns but had not been selected by indigenous women themselves. As a consequence, they decided they needed their own space to deliberate how they would participate in the Beijing process, convening the First Continental Encuentro of Indigenous Women of the First Nations of Abya Yala in August 1995 in Quito, Ecuador. At that historic meeting the Coordinadora Continental de Mujeres Indígenas formed as the first network of indigenous women's organizations spanning all of North, Central, and South America. The Second Continental Encuentro of Indigenous Women met in Mexico City in 1997, the Third Encuentro was held in Panama in March 2000, and a Fourth Encuentro is scheduled to be held in Peru in 2003.

\section{Reframing exclusion: “Cultural racism” and linguistic diversity at Juan Dolio}

Though marked by an almost total absence of women who identified as indigenous, the presence of hundreds of women of African descent far exceeded their participation in previous Encuentros. As the first Encuentro to be held in the Caribbean, the Juan Dolio gathering also shed new light on ongoing feminist debates about diversity, given the historical, cultural, linguistic, and demographic specificity of that region.

Political tensions and linguistic difficulties surfaced at the Juan Dolio meeting. They were fueled by the historically racialized antagonism toward and Dominican Republic's proximity to Haiti, the first (and only) Black republic in the Americas, created upon gaining independence from France two hundred years ago. In fact, several Caribbean activists drew attention to the fact that a manifestation of the human rights abuses routinely suffered by migrant 
Haitian workers was taking place precisely at the time of the meeting: the forcible expulsion of "unnecessary" workers from the Dominican Republic regardless of immigration status. A veteran Dominican feminist argued that given the longstanding tensions between the nations, Haitian women who attended "should have been treated 'with kid gloves' (guantes de seda)." Instead, forms of exclusion that inextricably wove together race issues and linguistic differences underscored the hegemony of Spanish-speaking women, who largely identified as being of European or mixed descent despite the complaints of their English- and French-speaking "sisters" who identified as of African descent.

The Eighth Encuentro seems to have exacerbated or at least not helped to overcome some of the divisions between Anglo- and Francophone Caribbean and Dominican feminists. In an interview, veteran Dominican feminist, Sergia Galván, confirmed that the number of Caribbean women in attendance at the Encuentro was disappointingly low and attributed it to an historic tendency of Dominican feminism to look to the rest of Latin America rather than to the Caribbean: "Ever since the first Feminist Encuentro, we have emphasized the need to construct spaces where Caribbean feminists can develop links and now that the Encuentro takes place in the Dominican Republic, in the Caribbean, [Caribbean feminists] are in the total minority, which reflects not only communication problems among us, but a lack of understanding of who we are as Caribbeans."

These tensions culminated during the plenary sessions where originally only makeshift translation by volunteers with no amplification was provided in the corners of the room. This led, during the first plenary, to the explosive exit of the frustrated Haitian delegation—which could not help but view this occurrence as an incident of cultural racism—and the no-lessimpassioned calls for its return on the part of the rest of the crowd. From then on, consecutive 
translation by volunteers in French, English, and Portuguese, with amplification, was provided. But translation was muted by the disrespectful chatter of those who did not need it and was later cut down to French only due to time constraints.

The restraining effect of the hegemonic use of Spanish on the participation of nonSpanish speaking women was nothing new (especially for Portuguese speakers). However, it was greatly heightened in Juan Dolio as a result of the geopolitical relations between Haiti and the Dominican Republic and the unavoidable conflation of race and language issues in this situation, as well as the continuing lack of sustained discussion of racism at Juan Dolio. The need to examine race and other issues of diversity more profoundly at future Encuentros was argued emphatically by a group women of African descent in a manifesto they read at the end of the meeting in the four languages spoken at the meeting. Finally, the presence and discourse of diaspora women with heightened sensitivity to issues of racism and migration, and therefore to the plight of Haitian women migrants in the Dominican Republic, certainly added kindling to the fire.

\section{Women of the Latin American and Caribbean diaspora in the United States and Europe}

As living testimony to an increasingly interdependent and historically transnational "Latin/a American" community, an unprecedented number of women of Caribbean and Latin American origin living as immigrants or exiles in the United States (particularly Dominican and Puerto Rican women from the East Coast) attended the Encuentro. As a consequence, the geographical boundaries of the imagined Latin American feminist community were dramatically remapped at the Juan Dolio meeting. Whereas a handful of Latinas from the United States and Europe had participated since the First Encuentro and were still counted as "foreign participants" 
by the organizers of the Fourth in Mexico in 1987, they attended the Juan Dolio meeting by the hundreds (Alvarez 2000, 34). In addition, the Eighth Encuentro's program included, for the first time, numerous sessions devoted to issues—-such as immigrant rights and racism—confronting women in the Latin American and Caribbean diaspora. Afro-Caribbean women from that diaspora, along with many "white" and mestiza Chicana/Latinas who in U.S. and European racial formations are, of course, politically situated as nonwhite or "brown," often coalesced with women of African descent residing in Latin America and the Caribbean in calling attention to the ways in which racism deeply shapes women's experience and life chances, challenging EuroLatin American and mestiza feminists to not only "embrace diversity" but also confront inequality among women.

U.S. Latinas conducted a number of workshops at Juan Dolio, including one on the myths and realities of immigrant women's lives in the United States titled "Transgresión de Fronteras" [Transgressing borders]. The workshop, organized by Dominican and Puerto Rican activists from the New York City area, included a psychotherapist, a social worker, an activist against domestic violence, and the head of an organization of grandmothers raising their grandchildren (often due to problems such as domestic violence, incest, or the imprisonment or substance abuse of their parents). One of their main goals was to dispel the myth of a life on "easy street" for immigrant women in the United States, particularly in light of deteriorating conditions in cities such as New York, cuts in social services, and immigration restrictions. They also wanted women elsewhere to know that they were organizing to address immigrant community problems and to establish alliances across borders. 


\section{Heightened awareness of the local effects of globalization and neoliberalism}

While the issue of class has always been central to the region's feminisms, the rapid accentuation of inequalities stemming from the spread of neoliberal capitalism and the complex outcomes of globalization brought economic exploitation and its intersection with gender and race to the fore of many debates at the Eighth Encuentro. Many participants gave witness to the complexity of economic oppression in the lives of women in the region, especially for urban and rural poor women who are hardest hit by economic restructuring, and repeatedly emphasized the need for a feminist response. Although the format and methodology of the gathering did not allow for systematic analysis of economic change or the elaboration of collective responses to it, substantial agreement seemed to exist on its importance and implications.

On one hand, neoliberal policies, many participants argued, have accelerated women's poverty and increased the burden of their "double or triple day" through the simultaneous devolution of public services to the household and the increase in women's need to perform paid work outside the home. Cuts in public funding and reliance on the vagaries of the market have accentuated a culture of individualism, competition, and conflict over scarce resources, making it difficult to pursue collective solutions to social problems and to effectively enforce rights gained as the result of struggles in the previous decade. Development projects have become focused on teaching women how to manage poverty individually rather than on collectively mobilizing them to reduce it at a societal level. Even projects with common goals compete with each other for funds-from international sources, and local agendas are often compromised to adapt to external priorities. In the neoliberal world of "projects" for social change, long-term visions of change often have been substituted for practical short-term "results." 
Many insisted, on the other hand, that globalization also presents new opportunities for feminist organizing. Throughout Latin America and across the globe, the technological revolution in communications makes it possible for some feminists to exchange information, write and sign manifestos, plan conferences, strategize about political action, and share dreams of new utopias unhampered by geographical constraints. At the same time, however, connection to the global may result in inattention to or a distorted interpretation of local conditions. Furthermore, uneven access to technological resources such as electronic mail and the Internet can exacerbate preexisting inequalities and exclusionary practices.

Undoubtedly, the effects of neoliberalism and globalization pose a multitude of strategic questions. "How," wondered one participant, "are we supposed to navigate in a world in which so much has changed?" Others underscored the need to move beyond criticisms of what exists in order to formulate concrete proposals for change (“de la queja a la propuesta” [from complaint to proposal]). Still others emphasized the need to advance alternative models of globalization and learn to manage "degrees of negotiation" vis-à-vis the rest of civil society and other social movements that allow them to negotiate an ethical stance "entre la política de lo posible y la transgresión" [between the politics of the possible and transgression]. Reflecting this heightened feminist engagement with global political-economic inequality, the organizers of the Ninth Latin American and Caribbean Feminist Encuentro, to be held in Playa Tambor, Costa Rica, in December 2002, have designated “Active Resistance to Globalization” as the meeting's overarching theme.

\section{$\underline{\text { Concluding reflections }}$}

The Encuentros, like feminisms themselves, are arenas of solidarity and expansion, but also of conflict and exclusion, negotiations, and renegotiations. These dynamics do not take 
shape in a vacuum but are always informed by the changing political and economic contexts in which feminisms unfold. Since the Encuentros began, the political landscape of Latin America has shifted dramatically, from a period in which dictatorships and open political repression flourished to a time when almost all of the countries in the region claim to be at least de jure if not de facto democracies. While economic crisis seems to typify the entire period, economic development models have also been transformed, moving from state-led to market-driven or neoliberal capitalism within an increasingly globalized arena. These contextual shifts in turn have reshaped the choices different feminists have made to interact with actors and institutions outside of the feminist movement, whether these are Leftist movements, parties, State agencies, international funders, or the larger women's movements in all their diversity.

These interactions have been informed by changing and continually contested meanings of autonomy, which, in turn, have generated shifting criteria of inclusion and exclusion in the imagined regional feminist community. From what should feminists be independent? Parties? The State? Other women's movements? Foundations? And who can be accepted as "feminist": faveladas? Latina gringas? Institucionalizadas?

But perhaps most important to both sets of criteria is: quien decide-who decides? The answer has become less and less clear, as feminism's "Others" articulate "Other feminisms"ones, moreover, that insist that recognizing diversity, while necessary, is not a sufficient answer to taking inequality seriously. Instead, the difficult work of bringing to the fore the real inequities in power and privilege, whether generated by class, race/culture, sexual identity, location, or age, must be part and parcel of feminist analysis and prescription.

These will not be new issues to those engaged in feminist theorizing and practice beyond the Latin American region. However, analyzing their negotiation over the past twenty years in 
the richly textured experiences of the Encuentros and similar transnational movement sites may well provide new insights into debates over the postmodern fragmentation so celebrated by some and bemoaned by others within the international feminist community.

As participant-analysts of the Encuentros, moreover, we too have negotiated interpretive, political, disciplinary, and generational differences in the process of writing this essay. And we too have learned much from the tensions that inevitably surface in such collaborative endeavors. But we feel our experience reflects a crucial lesson from the Encuentros: while time-consuming and often frustrating, attempts at communication across various divides are always productive in some sense-whether such production "sees the light of day" or informs participants' lives and work in some less tangible way.

Tracking the Encuentros from our different locations, moreover, has enabled us to assess a number of shifts in movement dynamics, discourses, and practices that would have been difficult, if not impossible, to apprehend through locally-focused ethnographic methods alone. We believe that "transnational ethnographies" of events such as the Encuentros can enable analysts to better situate local and national movement actors and actions within a broader comparative framework. The kind of supralocal ethnographic research we undertook in this project permitted us to assess the dynamic interactions among diverse actors who identify with feminism and to observe the enactment and reformulations of alliances, collusions, conflicts, and outright confrontations among them. Transnational movement sites also offer unique insights into the uneven flows of power within movements, particularly if we pay close attention to who speaks, which voices become hegemonic, whose issues or interests predominate, who is absent or present but silenced. In short, tracking regional and global movement gatherings enables 
scholars to extend ethnography beyond the confines of the local, offering unique opportunities to craft ethnographies of transnational activism.

Reading movements through or at transnational sites only makes methodological sense, however, if one can ground those interpretations in local and national ethnographies and histories. If one cannot situate diverse Encuentro participants in their local contexts, there is, of course, a strong likelihood of misreading what transpires in transnational movement spaces. Collaborative research among scholars with extensive knowledge of diverse localities therefore serves as a crucial corrective, making it possible to check individual interpretations against those of colleagues familiar with local/national contexts other than those in which one has conducted in-depth research. In light of accelerated globalization and the concomitant intensification of transnational activism, the kind of collaborative, multisited ethnographic research strategies we have undertaken in analyzing feminisms through the lens of the regional Encuentros increasingly will be essential to more fully apprehend movement dynamics at the local and national levels.

Finally, beyond this academic site of knowledge production, the experience of the Encuentros demonstrates how imperative it is that feminists in the so-called global women's movement nourish, sustain, reinvent, and recreate these sorts of productive transnational movement sites (both virtual and "real"), parallel to, but always in interaction and creative tension with, official intergovernmental venues - such as the UN - which also have been crucial to the forging of feminist identities, discourses, and practices.

The authors would like to thank the many Latin American and Caribbean feminists who have shared their insights, words and time with us. 
${ }^{1}$ The three authors who served as coordinators and principal editors of the various drafts of this collaborative piece are listed first; the remaining coauthors appear in alphabetical order.

${ }^{2}$ Comité Organizador del VIII Encuentro, “Convocación General,” July 1999.

${ }^{3}$ One of us has participated in all eight of the Latin American and Caribbean Feminist Encuentros, another in five, one in three, two of us in two, and three in one of these regional meetings. Among us, we have conducted research and participated in innumerable local and national feminist and women's movement activities in Argentina, Brazil, Chile, Peru, Colombia, Nicaragua, Cuba, Guatemala, El Salvador, Venezuela, and Mexico. Additionally, several of us have attended and conducted research on Latin American women's involvement in various UN conference processes, including Nairobi, Rio, Vienna, Cairo, and Beijing. We also bring our diverse range of feminist political and intellectual trajectories and cultural, racial-ethnic, sexual, geographic, and generational perspectives to the writing of this essay. Collectively, our research and teaching span a range of disciplines: history, literature, cultural studies, anthropology, sociology, and political science.

${ }^{4}$ This designation marks the shift from Cold War geopolitical demarcations of first/third world to emphasize the realignment of capital and power along a North/South axis in the current neoliberal context of globalization.

${ }^{5}$ For a sampling of this literature, see Fraser 1987; Stienstra 1994; Friedman 1995; Stephenson 1995; Abzug 1996; Chen 1996; Kardam 1997; Clark, Friedman, and Hochstetler 1998; Keck and Sikkink 1998; Meyer and Prugl 1999; and Basu 2000.

${ }^{6}$ For other recent overviews of Latin America's feminist movements, see especially Alvarez 1998; Jaquette and Wolchik 1998; Navarro and Bourque 1998; Craske 2000; DAWN 2000; Molyneux 2000; Vargas 2000; Barrig 2001; and Franco 2001. 
${ }^{7}$ On the movimientos de mujeres, see especially Jelin 1990; Lind 1992, 1995; and Stephen 1997, 1998.

${ }^{8}$ In the 1970 s "the magic word incorporated was autonomy, understood by each group in a different manner. Autonomy in relation to men (many), autonomy from political parties (some), and autonomy in relation to the state (everyone)" (Shumaher and Vargas 1997, 129).

${ }^{9}$ Peruvian feminist Ana María Portugal (1986) notes that Leftist women originally viewed “braburning" U.S. feminists as "bored gringas"; however, as "the comrades continued to wear their feudal armor at home, the domestic world in which the revolution will not occur," more and more women began to take feminism seriously (10).

${ }^{10}$ Maruja Barrig $(1994,159)$ cites a 1980 document signed by a group of Peruvian feminists. ${ }^{11}$ See II Encuentro Feminista Latinoamericano y del Caribe, 1984.

12 On women in human rights movements, see Navarro 1989; Taylor 1997; and Arditi 1999. On women's participation in grassroots survival struggles, see Caldeira 1990; Jelin 1990; Massolo 1991; Bennett 1992; Lind 1992; and Stephen 1997.

${ }^{13}$ At the final plenary session, it was declared, "All women who fight to improve the objective situation of the female gender will be considered feminists." The históricas were criticized as "those founders of feminism who have intellectually appropriated it for themselves, and who employ categories that are not only obsolete but also discriminatory against women who are approaching the movement" (Gargallo 1991, 15-16).

${ }^{14}$ On recent gender policy gains of the 1990s, see Nelson 1996; Htun 1998; Jaquette and Wolchik 1998; Santos 2000; and Tamayo 2000.

15 These conferences included the 1992 United Nations Conference on Environment and Development, held in Rio de Janeiro; the 1993 World Conference on Human Rights, held in 
Vienna; the 1994 UN Conference on Population and Development, held in Cairo; the 1995 Fourth World Conference on Women, held in Beijing; the 1995 World Summit for Social Development, held in Copenhagen; and the 1996 Second UN Conference on Human Settlements (Habitat II), held in Istanbul.

${ }^{16}$ Official governmental UN conferences usually are accompanied by a parallel meeting or "forum" for nongovernmental organizations.

${ }^{17}$ On the local, national, and regional impact of preparations for and participation in the Beijing preparatory process by Latin American and Caribbean feminists, see Amado 1995; Asturias 1995; Faccio 1995; Rodríguez A. 1995; and Vargas 1996; Alvarez 1998; Franco 1998; Lebon 1998; Mauleón 1998; Friedman 1999; and Friedman, Hochstetler, and Clark 2000.

18 The focal points were coalitions of women's NGOs and individual activists established in the following UN-designated subregions: Mexico, Central America, the Caribbean, the Andean Region, the Southern Cone, and Brazil.

${ }^{19}$ Formal interview with Gina Vargas and Cecilia Olea, Centro Flora Tristán and Regional NGO Coordination for Beijing, Lima, Peru, 19 August, 1997, conducted by Sonia E. Alvarez.

${ }^{20}$ It is important to note, as explained below, that those it was intended to describe did not adopt this term. However, feminists in Latin America who routinely engage with formal institutions are known as "institucionalizadas" or the less pejorative "institucionales."

${ }^{21}$ On Chilean feminist movement dynamics in the 1990s, see especially Frohmann and Valdés 1995; Valdés and Weinstein 1997; Guerrero and Ríos 1998; Valenzuela 1998; Fitzsimmons 2000; Schild 1998; and Ríos 2000.

${ }^{22}$ Información sobre la Medodología en el Trabajo con los Ejes Politicos; distributed by the Organizing Committee at the Encuentro. 
${ }^{23}$ On the contrary, there are many voices and proposals. Margarita Pisano explains that the current is composed of at least three main trends: one closely linked to a type of "cultural feminism" to which a number of the Juan Dolio organizers adhered; another identified with a stronger class-based discourse where many ex-"ultra left" -wing militants find themselves today—a group that has demonstrated significant ties to popular women's groups; and finally, a third that identifies itself as the "pure" autónomas, who rally around some of the most prominent historic figures within this trend of thought and who are far from both cultural feminism or a purely class discourse (Rios, Godoy and Guerrero, 2002). Members of this latter group have functioned as ideologues for the autónomas and, by and large, have been the ones unable to engage in any kind of meaningful political dialogue with other feminists with different political or ideological positions.

${ }^{24}$ Interview with Alexandra Ancheita, organizer of the feminist youth conference and member of the editorial group of Lunatika, conducted by Maylei Blackwell, March 15, 1999, tape recording, offices of K'inal Antsetik, Mexico City.

${ }^{25}$ Coordinated by Norma de la Cruz, Lunatika can be reached at Vicente Suárez 146-12 Col.

Romz, México D.F., C.P. 06140 or by e-mail: lunatikamex@yahoo.com.

26 "Declaración de las Jóvenes Feministas" 1999.

27 "Declaración de las Jóvenes Feministas" 1999.

${ }^{28}$ For more information on indigenous women's organizing in the region, see especially chaps. 3-5 in Blackwell 2000. 


\section{References}

Abzug, Bella. 1996. “A Global Movement for Democracy.” Women's Studies Quarterly 24 (1\&2): 117-22.

Alvarez, Sonia E. 1998. "Latin American Feminisms 'Go Global': Trends of the 1990s and Challenges for the New Millennium." In Cultures of Politics/Politics of Cultures: Revisioning Latin American Social Movements, ed. Sonia E. Alvarez, Evelina Dagnino, and Arturo Escobar, 293-324. Boulder, CO: Westview Press. . 1999. "Advocating Feminism: The Latin American Feminist NGO 'Boom.”, International Feminist Journal of Politics 2 (1): 181-209. .2000. "Translating the Global: Effects of Transnational Organizing on Latin American Feminist Discourses and Practices." Meridians: A Journal of Feminisms, Race, Transnationalism 1 (1): 29-67.

Amado, Ana Maria. 1995. “El Neo Papismo de Menem.” Fempress 167 (September): 3. Ancheita, Alexandra. 1999. Interview by Maylei Blackwell. Tape recording. Offices of K'inal Antsetik, Mexico City, March 15.

Arditti, Rita. 1999. Searching for Life: Grandmothers of the Plaza de Mayo and the Disappeared Children of Argentina. Berkeley: University of California Press.

Asturias, Laura E. 1995. "El Presidente y las Conferencias Mundiales.” Fempress 166 (August): 2.

Barrig, Maruja. 1994. “The Difficult Equilibrium between Bread and Roses: Women’s Organizations and Democracy in Peru." In he Women's Movement in Latin America: Participation and Democracy, 2nd ed., ed. Jane Jaquette, 151-176. Boulder, Colo.: Westview Press. 
. 2001. "Latin American Feminisms: Gains, Losses and Hard Times." NACLA

Report on the Americas 34 (March/April): 29-35.

. 2001. El Mundo al Revés: Imágenes de la Mujer Indígena. Buenos Aires:

\section{CLACSO.}

Basu, Amrita. 2000. "Globalization of the Local/Localization of the Global: Mapping Transnational Women's Movements." Meridians 1 (Autumn): 68-84.

Bennett, Vivienne. 1992. "The Evolution of Urban Popular Movements in Mexico Between 1968 and 1988." In The Making of Social Movements in Latin America: Identity, Strategy, and Democracy, eds. Arturo Escobar and Sonia E. Alvarez, 240-259. Boulder: San Francisco.

Blackwell, Maylei. 2000. “Geographies of Difference: Mapping Multiple Feminist Insurgencies and Transnational Public Cultures in the America.” Ph.D. diss., University of California, Santa Cruz.

Caldiera, Teresa Pires de Rio. 1990. "Women, Daily Life and Politics." In Women and Social Change in Latin America, ed. Elizabeth Jelin, 47-78. Trans. J. Ann Zammit and Marilyn Thompson. New Jersey: Zed Books.

Chen, Martha Alter. 1996. “Engendering World Conferences: The International Women's Movement and the UN." In NGOs, the UN and Global Governance, ed. Thomas G. Weiss and Leon Gordenker, 139-58. Boulder, Colo.: Lynne Rienner.

Clark, Ann Marie, Elisabeth J. Friedman, and Kathryn Hochstetler. 1998. “The Sovereign Limits of Global Civil Society: A Comparison of NGO Participation in UN World Conferences on the Environment, Human Rights, and Women.” World Politics 51 (1): 135. 
Comisión Organizadora del VII Encuentro. 1996. Convocatoria. Flyer.

Comisión Organizadora del VIII Encuentro. 1999a. Convocación General: Presentación. Email communication.

Comisión Organizadora del VIII Encuentro. 1999b. Información sobre la Medodología en el Trabajo con los Ejes Políticos. Flyer.

Cotidiano mujer, III época, no. 22 (Mayo 1996): 3

Craske, Nikki. 1998. "Remasculinisation and the Neoliberal State in Latin America." In Gender, Politics, and the State, ed. Vicky Randall and Georgina Waylen, 100-120. London:

Routledge. 2000. Continuing the Challenge: The Contemporary Latin American Women's Movement $(s)$. Research paper 23, Institute of Latin American Studies, University of Liverpool, Liverpool, UK.

Declaración de las Jóvenes Feministas. 1999. Flyer.

"Desde 'ni las unas ni las outras' hacia las 'unas' y las 'otras.” 1998. In Encuentros, (Des)encuentros y Búsquedas, ed. Cecilia Olea Mauleón, 225-28. Lima: Ediciones Flora Tristán.

Development Alternatives with Women for a New Era (DAWN) and Red de Ed ucación Popular Entre Mujeres de América Latina y el Caribe (REPEM), ed. 2000. De Poderes y Saberes: Debates sobre Reestructura Política y Transformación Social, Memória del II Seminario Regional. Montevideo, Uruguay: DAWN; REPEM.

dos Santos, Maria Cecília Mac Dowell. 2000. “Gender, the State, and Citizenship: Women’s Police Stations in São Paulo, Brazil.” In Irrumpiendo en lo Público: Seis Facetas de las Mujeres en América Latina, ed. Sara Poggio and Montserrrat Sagot, 63-92. San José, 
Costa Rica; Pittsburgh, Pa.: Maestría Regional en Estudios de la Mujer, Universidad de Costa Rica; Universidad Nacional; Latin American Studies Association.

Faccio, Alda. 1995. Muchos Caminos Hacia Beijing. Fempress 153 (July): 4.

Fisher, Amalia. 1995. "Los Encuentros Feministas: en busca del rumbo perdido o de uno Nuevo." In Reflexiones desde el movimiento feminista autónomo, ed. Movimiento Feminista Autónomo, 27-46. Santiago: n.p.

Fitzsimmons, Tracy. 2000. Beyond the Barricades: Women, Civil Society, and Participation after Democratization in Latin America. New York: Garland Publishing.

Franco, Jean. 1998. “Defrocking the Vatican: Feminism's Secular Project.” In Cultures of Politics/Politics of Cultures: Re-visioning Latin American Social Movement, ed. Sonia E. Alvarez, Evelina Dagnino, and Arturo Escobar, 278-89. Boulder, Colo.: Westview Press. . 2001. "Bodies in Contention." NACLA Report on the Americas 34 (5): 41-44.

Fraser, Arvonne S. 1987. The UN Decade for Women: Documents and Dialogue. Boulder, Colo.: Westview Press.

Friedman, Elisabeth. 1995. “Women's Human Rights: The Emergence of a Movement.” In Women's Rights Human Rights: International Feminist Perspectives, ed. Julie Peters and Andrea Wolpers, 18-35. New York: Routledge. . 1999. "The Effects of 'Transnationalism Reversed' in Venezuela: Assessing the Impact of UN Global Conferences on the Women's Movement." International Feminist Journal of Politics 1 (3): 357-81.

Friedman, Elisabeth Jay, Kathryn Hochstetler, and Ann Marie Clark. 2000. "Sovereign Limits and Regional Opportunities for Global Civil Society in Latin America." Latin American Research Review 36 (3): 7-36. 
Frohmann, Alicia, and Teresa Valdés. 1995. "Democracy in the Country and in the Home: The Women's Movement in Chile." In The Challenge of Local Feminisms: Women's Movements in Global Perspective, ed. Amrita Basu, 276-301. Boulder, Colo.: Westview Press.

Galván, Sergia. 1995. “El Mundo Étnico-Racial Dentro del Feminismo Latinoamericano.” In Fempress (Special issue on La Mujer Negra): 34-36

Gargallo, Francesca. 1991. “Los Encuentros del Desencuentro.” fem, no. 93 (February): 15-16. Guerrero, Elizabeth, and Marcela Ríos. 1998. "El Camino que Lleva a la Plaza: Delineando el Campo de Acción Feminista Hoy.” In Reflexiones Teóricas y Comparativas sobre los Feminismos en Chile y América Latina, ed. Marcela Ríos, 23-31. Santiago: Notas del Conversatorio.

Htun, Mala. 1998. “Women's Rights and Opportunities in Latin America: Problems and Prospects." Issue brief for the Women's Leadership Conference of the Americas, InterAmerican Dialogue, Washington, D.C. Available at $<<$ http://www.iadialog.org $>>$

Jaquette, Jane S., and Sharon L. Wolchik, eds. 1998. Women and Democracy: Latin America and Eastern Europe. Baltimore: Johns Hopkins University Press.

Jelin, Elizabeth, ed. 1990. Women and Social Change in Latin America. London: Zed.

Kardam, Nuket. 1997. “The Emerging International Women’s Regime.” Unpublished manuscript.

Keck, Margaret E., and Kathryn Sikkink. 1998. Activists beyond Borders: Advocacy Networks in International Politics. Ithaca, N.Y.: Cornell University Press. 
Lebon, Nathalie. 1993. "The Brazilian Feminist Movement in the Post-Constitutional Era: Assessing the Impact of the Rise of Feminist Non-Governmental Organizations.” Florida Journal of Anthropology 18: 17-26.

Lebon, Nathalie. 1998. "The Labor of Love and Bread: Volunteer and Professionalized Activism in the São Paulo Women’s Health Movement.” Ph.D. diss., University of Florida.

Lidid, Sandra, and Kira Maldonado. 1996. "Palabras Iniciales." In Movimiento Feminista Autónomo (1993-1996), ed. Kira Maldonado and Sandra Lidid, 2-4. Santiago: Ediciones Número Crítico.

Lind, Amy C. 1992. “Power, Gender, and Development: Popular Women’s Organizations and the Politics of Needs in Ecuador." In The Making of Social Movements in Latin America: Identity, Strategy, and Democracy, ed. Aurturo Escobar and Sonia Alvarez, 134-49. Boulder, Colo.: Westview. . 1995. “Gender, Development and Women's Political Practices in Ecuador.” Ph.D. diss., Cornell University.

Manrique, Frida. 1981. "Lo Encuentro Feminista Latinoamericano y del Caribe." Mujer y sociedad, nos. 4-5 (September.-October): 2-4.

Massolo, Alejandra, ed. 1992. Mujeres y Ciudades: Participación social, vivienda y vida cotidiana. México, D.F.: El Colegio de México.

Mauleón, Cecilia Olea, ed. 1998. Encuentros, (Des)Encuentros y Búsquedas: El Movimiento Feminista en América Latina. Lima: Ediciones Flora Tristán.

Mello, Fatima Vianna. 1994. “Aceptar o no Aceptar el Dinero? Is That the Question?” Fempress 148/49 (February/March): 28-29. 
Meyer, Mary K., and Elisabeth Prugl, eds. 1999. Gender Politics in Global Governance. New York: Rowman \& Littlefield.

Mogrovejo, Norma. 1998. "Sexual Preference, the Ugly Duckling of Feminist Demands: The Lesbian Movement in Mexico." In Female Desires: Same Sex Relations and Transgender Practices across Cultures, ed. Evelyn Blackwood and Saskia Wieringa, 308-35. New York: Columbia University Press. . 2000. Un Amor Que Se Atrevió a Decir Su Nombre: La Lucha de las Lesbianas y su Relación con los Movimientos Homosexual y Feminista en América Latina. México, D.F.: Plaza y Valdés Editores; Centro de Documentación y Archivo Histórico Lésbico 'Nancy Cárdenas.'

Molyneux, Maxine. 2000. "Twentieth-Century State Formations in Latin America." In Hidden Histories of Gender and the State in Latin America, ed. Elizabeth Dore and Maxine Molyneux, 33-84. Durham, N.C.: Duke University Press.

Murdock, Donna F. Forthcoming. “Localizing the Global: Women's NGOs and Bureaucratic Discipline in Medellin.” Ph.D. dissertation, Emory University.

Navarro, Marysa. 1989. “The Personal is Political: Las Madres de la Plaza de Mayo.” In Power and Popular Protest: Latin American Social Movements, ed. Susan Eckstein, 242-58. Berkeley and Los Angeles: University of California Press. . 1998. “Una Reflexión: Notas sobre Uno de los Posibles Mapas del Feminismo Latinoamericano para Ir Creando Futuras Cartografías." In Encuentros, (Des)Encuentros y Búsquedas: El Movimiento Feminista en América Latina, ed. Cecilia Olea Mauleón, 97-112. Lima: Ediciones Flora Tristán. 
Navarro, Marysa, and Susan C. Bourque. 1998. "Fault Lines of Democratic Governance: A Gender Perspective." In Fault Lines of Democracy in Post-Transition Latin America, ed. Felipe Aguero and Jeffrey Stark, 175-202. Miami: North-South Center Press.

Nelson, Sara. 1996. “Constructing and Negotiating Gender in Women's Police Stations in Brazil." Latin American Perspectives 23 (1): 131-54.

Portugal, Ana María. 1986. “Qué es ser feminista en América Latina?” In Movimiento Feminista, Balance y Perspectivas. Isis International. Santiago: Ediciones de las Mujeres.

Ríos, Marcela. 2000. "Feminismo(s) Chileno en los Noventa: Paradojas de una Transición Inconclusa." Cuadernos de Investigación Social No. 9, Departamento de Ciencias Sociales, Pontífica Universidad Católica del Perú, Lima, Perú.

Rios Tobar, Marcela, Lorena Godoy \& Elizabeth Guerrero. 2002. El movimiento de feminista en el Chile: actores sociales y transición a la democracia. Santiago: Centro de Estudios de la Mujer. Unpublished Manuscript.

Rodríguez A., María Lis. 1995. “Agua Fria Camino a Beijing.” Fempress 167 (September): 5. II Encuentro Feminista Latinoamericano y del Caribe. 1984. Special issue of Revista de las Mujeres, no. 1 (June): 91.

Schild, Verónica. 1998. “New Subjects of Rights? Women’s Movements and the Construction of Citizenship in the 'New Democracies.'” In Cultures of Politics/Politics of Cultures: Re-visioning Latin American Social Movements, ed. Sonia E. Alvarez, Evelina Dagnino, and Arturo Escobar, 93-117. Boulder, Colo.: Westview Press.

Shumaher, Maria Aparecida, and Elisabeth Vargas. 1997. "Lugar en el gobierno: ¿Alibi o conquista?" Debate Feminista 15 (April): 128-47. 
Stephen, Lynn. 1997. Women and Social Movements in Latin America: Power from Below. Austin: University of Texas Press. . 1998. "Gender and Grassroots Organizing: Lessons from Chiapas.” In Women's Participation in Mexican Political Life, ed. Victoria E. Rodríguez, 146-66. Boulder, Colo.: Westview Press.

Stephenson, Carolyn M. 1995. "Women’s International Nongovernmental Orga nizations at the United Nations.” In Women, Politics, and the United Nations, ed. Anne Winslow, 13453. Westport, Conn.: Greenwood Press.

Sternbach, Nancy Saporta, Marysa Navarro-Aranguren, Patricia Chuchryk, and Sonia E. Alvarez. 1992. "Feminisms in Latin America: From Bogota to San Bernardo." Signs: Journal of Women in Culture and Society 17 (2): 393-434.

Stienstra, Deborah. 1994. Women's Movements and International Organizations. New York: St. Martin's Press.

Tamayo, Giulia. 2000. "Derechos Humanos de las Mujeres, Violencia contra la Mujer, y Paz en la Región: Revisión de Avances y Desafíos a Cinco Años de la Cuarta Conferencia Mundial sobre la Mujer." Informe preparado para la Articulación Regional sobre la Mujer de América Latina y el Caribe, ante la Octava Conferencia Regional sobre la Mujer de América Latina y el Caribe. Photocopy.

Taylor, Diana. 1997. Disappearing Acts: Spectacles of Gender and Nationalism in Argentina's “Dirty War.” Durham, N.C.: Duke University Press.

Valdés, Teresa, and Marisa Weinstein. 1997. “Corriendo y Descorriendo Tupidos Velos.” In Chile 96: Análisis y Opiniones, 67-77. Santiago: FLACSO-Chile. 
Valenzuela, María Elena. 1998. "Women and the Democratization Process in Chile.” In Women and Democracy: Latin America and Central and Eastern Europe, ed. Jane S. Jaquette and Sharon L. Wolchik, 47-74. Baltimore: Johns Hopkins University Press. Vargas, Virginia. 1996. "Disputando el Espacio Global: El Movimiento de Mujeres y la IV Conferencia de Beijing." Nueva Sociedad 141 (January/February): 43-54. . 1998a. "Carta hacia el VII Encuentro Feminista Latinoamericano y del Caribe.

Chile, 1996." In Encuentros, (Des) Encuentros y Búsquedas: El Movimento Feminista en América Latina, comp. Cecilia Ole Mauleón, 15-38. Lima: Ediciones Flora Tristán. . 1998b. "Knots in the Region." In Roads to Beijing: Fourth World Conference on Women in Latin America and the Caribbean, 1-14. Lima; Santafé de Bogotá; Quito: Ediciones Flora Tristán; UNICEF; UNIFEM.

. 1999. "Encuentros feministas: énfasis y estrategias." In Feminismos Plurales: VII Encuentro Feminista Latinoamericano y del Caribe. Aportes para el Debate 7 de la Agencia Lationamericana de Información, ALAI (November): 30-32. . 2000. "Institucionalidad Democrática y Estrategias Feministas en los Años 90. El Estado, las Mujeres y la Política a través de la Historia Latinoamericana.” In De Poderes y Saberes: Debates sobre Reestructura Política y Transformación Social, Memória del II Seminario Regional, ed. Development Alternatives with Women for a New Era (DAWN) and Red de Educación Popular Entre Mujeres de América Latina y el Caribe (REPEM), 33-72. Montevideo, Uruguay: DAWN; REPEM.

Vargas, Virginia, and Cecilia Olea Mauleón. 1997. Interview by Sonia E. Alvarez. Centro Flora Tristán and Regional NGO Coordination for Beijing, Lima, Peru, August 19, 1997. 
1998. "Roads to Beijing: Reflections from Inside the Process." In Roads to Beijing: Fourth World Conference on Women in Latin America and the Caribbean, 1538. Lima; Santafé de Bogotá; Quito: Ediciones Flora Tristán; UNICEF; UNIFEM. 